\title{
Local Site Visits as Medium of Establishing Social Identity for Adolescents at State High School 1 Ulujami
}

\author{
$1^{\text {st }}$ Grita Diding Sugiarto* \\ Postgraduate of History Education, \\ Yogyakarta State University \\ Yogyakarta, Indonesia \\ grita8171@gmail.com
}

\author{
$2^{\text {nd }}$ Dyah Kumalasari \\ Postgraduate of History Education \\ Yogyakarta State University \\ Yogyakarta, Indonesia \\ dyah_kumalasari@uny.ac.id
}

\author{
$3^{\text {rd }}$ Oktavia Prastyaningrum \\ Postgraduate of History Education \\ Yogyakarta State University \\ Yogyakarta, Indonesia \\ oktaviaprastyaningrum@gmail.com
}

\begin{abstract}
SMA Negeri 1 Ulujami is one of the educational institutions in the Pemalang Regency that implements visiting the location as a means of learning social science, especially history. The visit was carried out at several accessible local sites in the Pemalang Regency namely the New Comal Sugar Site, the New Comal Train Station Site, the Dutch House Site, and the Rowosari Bridge Site. Local site visit activities do not only support a massive learning system but on the other hand, also show effort from school to make the social identity of adolescents (students) as part of the Pemalang Regency social community group. Conversations established by students with friends, teachers, and local sites provide very important experience in the formation of social identity. This study aimed to identify social students of SMA Negeri 1 Ulujami during local visit activities using descriptive qualitative research methods. The social identity formed in SMA Negeri 1 Ulujami students was conveyed through four dimensions proposed by Jackson and Smith, including perceptions of intergroup contexts, interest in groups, interdependent trust, and depersonalization. The results of research conducted by researchers through observation, interviews, and observations show local visits have a positive influence on adolescent social identity at SMA Negeri 1 Ulujami that prioritizes pride in being part of the Pemalang District community.
\end{abstract}

Keywords - social identity, local site, adolescent, student

\section{INTRODUCTION}

Each region in Indonesia has characteristics of social groups that distinguish between one another. According to data in 2000, there were more than a thousand different ethnic and sub- ethnic groups in Indonesian territory [1]. Each social group claims to have its own social identity that has been formed since the interaction between the members.

Social identity is very dynamic and cannot be separated from the background of the conditions of the social region of each era. For example, the social life of colonialism helped form the social identities of local and national communities in Indonesia that had courage, openness, idealism, a spirit of devotion, and an innovation. In another case, in pre-colonial society, the emergence of new social identities is unstoppable, especially because social interaction is already quite global. According to Laar, Derks, Ellemers, and
Bleeker, the social identity of a community can be seen not as a problematic factor that needs to be minimized but can be utilized by positive social outcomes and increasing lowstatus groups [2]. Social identity plays an important role in connecting individual feelings with the group so that it can influence motivation to improve status through in-group support to increase individual mobility.

The introduction of social identity in a positive society is very important to instill values at an early stage, especially during the adolescence. The adolescent is an age that is identical to the find the identity. The adolescent stage is believed to be in a position of confusion and selfidentification. Erikson believes that the adolescent phase is the stage that really determines who we are as adults [3]. The development of adolescents is also influenced by social identities outside their community groups, especially through association with peers. Not a few adolescents who want to form a social identity like other groups that are considered high social statuses, such as public figures and urban society. Although individuals can shape themselves like other groups' social identities, it is not necessarily good to be implemented. As for adolescents who get negative relationships cause regression of social identity. Therefore, the introduction of social identity for adolescents is an important effort to do, because it can help individuals to better understand themselves and know how to place themselves in the social environment.

It means, creating social identity can be done by the community and other social groups. Althusser [4] provides two tools that can be used by the state to instill certain ideologies to the public, namely Repressive State Apparatus (RSA) and Ideological State Apparatus (ISAs). RSA is a state apparatus used by the authorities to maintain the status quo forcefully by using violence, such as prisons, police, and the army. Meanwhile, ISAs is a place where ideology is subtly implanted, such as schools, places of worship, families, and so on. Taking from Althusser's concept, school is an ISAs category that consists of social groups within the auspices of educational institutions that are miniatures of society for adolescents. In addition to science, schools also provide values and norms for adolescents in accordance with the social identity of the local community. 
Schools are considered capable of providing knowledge transfer and social reproduction in society, both in the same generation or involving people in different generations [5].

In this research, the researcher is interested in analyzing the existence of efforts to form a social identity in the school, namely SMA Negeri 1 Ulujami, through visiting activities at several local sites in the Pemalang Regency. Although many schools choose large cities as study tours, SMA Negeri 1 Ulujami instead carries out a learning program by prioritizing the potential that exists in the Pemalang District. There are not many schools that utilize local sites in their area as a means of learning as well as the formation of social identity for adolescents. The activity of visiting local sites carried out by SMA Negeri 1 Ulujami in which there are adolescents' interactions with one another. The material delivered by the teacher also revolves around the history of showing the privileges of the Pemalang community in the past, where it was not widely known by adolescents. Thus, this research is expected to provide new benefits around the local potential that can be used as a means of forming a positive social identity for adolescents.

\section{METHODS}

This research used a descriptive qualitative research approach. Descriptive qualitative research is a type of research that presents a general description of an object of the research. In line with the opinion of Sugiyono [6], qualitative research discusses a study in detail, so it must require many sources of data to be able to strengthen the research. In this study, researchers used a type of field research, where researchers collected data in the field by analyzing and presenting facts systematically about the state of the research object. The approach in qualitative research was chosen by researchers because it can provide detailed and detailed explanations in describing an event. This illustrates the actual situation to support the presentation of data.

Data collection was performed using three techniques, namely observation, interviews, and documentation. Researchers conducted direct observations when the implementation of activities took place starting from the departure of SMA Negeri 1 Ulujami until arriving at local sites, including the New Comal Sugar Factory Site, the New Comal Train Station Site, the Dutch Home Site, and the Rowosari Bridge Site. The researcher completed the data by interviewing three SMA Negeri 1 Ulujami teachers who accompanied the activities, as well as students who took part in visiting local sites. The students who were used as speakers numbered half of the population who participated, namely 16 people. Researchers also conduct literature studies as supplementary material in analyzing research objects.

This study aimed to describe the data and deeply analyze the process of forming a social identity for adolescents at SMA Negeri 1 Ulujami through visits to local sites in the Pemalang Regency. By looking at the existing problems, this research focuses on the process of adolescent interaction with friends, teachers, and local sites that shape social identity, as well as responses from adolescents about the activities of visiting local sites in the Pemalang Regency.
Researchers try to analyze data with all the wealth of character, as close as possible to the original form.

\section{LITERATURE REVIEW}

\section{A. Social Identiy}

This study used Henri Tajfel's social identity theory as an analysis tool for the process of forming a social identity that occurs in adolescents in the SMAN 1 Ulujami. According to Tajfel, social identity is part of the selfconcept of individuals that comes from their knowledge of their membership in social groups along with the value and emotional significance of the membership [7]. Someone will get a social identity if he has categorized himself as a member of a group in his environment. Self-categorization occurs when individuals place themselves as objects that can be categorized, classified, and named in certain ways in relation to other categories that exist in their social environment [8]. At the stage of self-categorization, a person tends to be able to see similarities between himself.

\section{1) Perceptions of the Intergroup Context}

Self-identification on a group will affect individual perceptions according to the status of the group. The perception then leads the individual to give an assessment, both in the group and other groups. In some instances, perceptions in the context of intergroup play an important role in both safe and insecure generational identities and the extent to which minority and majority social groups linked to two types of social identity that need further study.

\section{2) Attraction to the In-Group}

Individuals who join social groups are certainly based on certain reasons. Social groups can attract individuals to join because there is something unique and interesting, such as the clarity of the identity of the community, its structure and activities, the type of group, and the members. Feelings in groups that show loyalty to their members often lead to prejudice against outside groups. However, although social identity and group cohesion have theoretically been distinguished, the scale formed to access the two conceptions empirically is not compared and distinguished. In Jackson and Smith's framework, interest in groups is only one dimension of social identity.

\section{3) Interdependency Beliefs (Common Fate)}

Beliefs are interrelated as a dimension of social identity rooted in the Sherif's view of groups and the theory of intergroup relations. Based on Sheriff's views, norms and values govern the behavior of group members as they follow common goals and react to members within the group and outside the group. If individuals join a social group and have a social identity, then the individual will survive with their identity and feel comfortable with the social group that is followed. The individual who has confidence in their social groups will bring up emotional closeness. This closeness arises after realizing the existence as a member of a particular social group. People will use their social identity as pride and self-confidence. Reference group identification has been defined in terms of feeling 
interrelated or shared destiny, namely that self-identity and personal attraction are based on group members.

\section{4) Depersonalization}

The idea of depersonalization plays a prominent role in the theory of self-categorization, the theory of optimal distinctiveness, and the reconciliation of group cohesion as a social attraction. According to the theory of selfcategorization, social identity requires an increase in the level of depersonalization, ie a shift in self-perception as an example that can be exchanged from several social categories and away from self-perception as a unique person. When individuals feel like part of a group, then the individual tends to use the values in the group.

\section{B. Local Site}

The local site is a local location that contains objects of cultural heritage including the environment needed for security [11]. The classification of objects and environments that enter the site is at least 50 (fifty) years old or represents a unique style and is considered to have important value for science, culture, and history. The site includes part of cultural treasures that have important values. The site has a variety of uses such as objects of science, sources of data and historical evidence, cultural mirrors and national history, media education, development, and build of national cultural values, as well as media to foster national personality. Historical relics reflected on sites provide a priceless picture of past human life.

\section{RESULTS ANDDISCUSSION}

\section{A. The Pattern of Visiting Local Sites in The Pemalang Regency}

The activity of visiting local sites is a learning program conducted by the history teachers of SMA Negeri 1 Ulujami. According to the head of implementation who is also a senior history teacher at SMA Negeri 1 Ulujamil, Edy Kusmanta, the visit of historical sites is a new step for history learning which has so far been centered in the classroom [12]. When learning history takes place in the classroom, students tend to show passive interaction with the material presented, only a small proportion of students who dare to express opinions about the topic being discussed. Most students choose to remain silent and only listen. This has become a problem that history teachers want to solve at SMA Negeri 1 Ulujami because history contains many life lessons for students. If the historical content conveyed by the teacher does not reach the students, the learning process that has been running seems futile.

The history teachers of SMA Negeri 1 Ulujami who are members of the MGMP (Subject Teachers' Association) school-level association are aware that Pemalang Regency has many local sites that can be utilized. The Pemalang Regency has many local sites that are scattered in several sub-districts, even near the school and where students live. The local potential provided inspiration for Edy Kusmanta to hold a visit at local sites near the school, then Edy Kusmanta invited other history teachers to make the program a success. All history teachers at SMA Negeri 1
Ulujami also prepared all preparations and permits, starting from the coordination of the school principal and staff, students, site staff, and several sociology teachers also helped to assist while on site. At the time of the research, the activity was attended by representatives of students from class XI with a total of 32 people. Representatives of the students are given the task to convey all information related to the sites visited members of the group. Before the implementation of the activity, the history teacher had divided the discussion group into 4 sections in each class.

The visit of local sites starts from the site farthest site to the closest site from school, including the New Comal Factory Site, the New Comal Train Station Site, the Dutch House Site (Indische) in the Rowosari Village, and the Rowosari Bridge Site. While at the site location, students were given material about the history of the site and how the life of the Pemalang community in the period the site was built. The provision of material is given directly by the history teacher through a scientific approach and officers who maintain the location of the site. After giving the material, students are given the freedom to ask questions, discuss with friends, and explore the building sites, but still pay attention to the rules that have been delivered by the accompanying teacher before. Visiting activities at several local sites in the Pemalang Regency lasted quite a long time starting from 07.00 a.m. until before 03.00 p.m. However, researchers found no complaints and boredom from students, but instead, they were very enthusiastic about every direction and the existence of local sites.

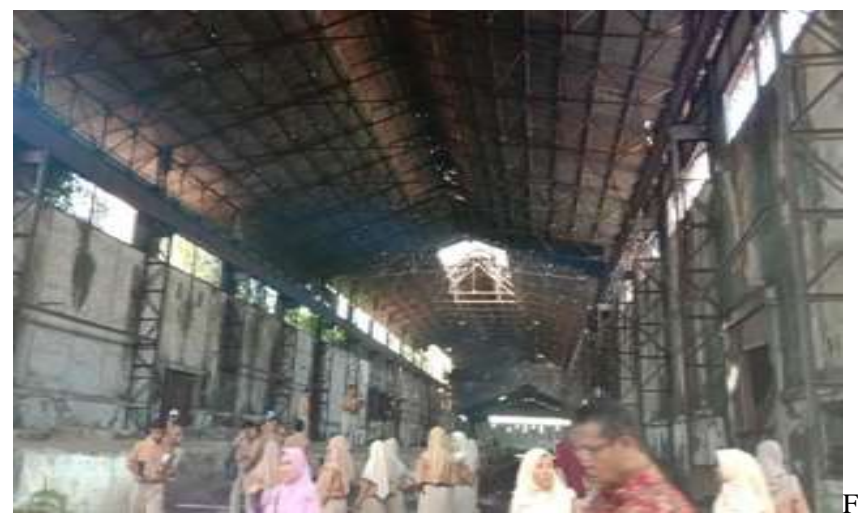

igure 1: The Activity of Visiting at the New Comal Factory Site Source: private document

History teachers at SMA Negeri 1 Ulujami have high expectations from visiting local sites in the Pemalang Regency. Aside from being a learning material, history teachers of SMA Negeri 1 Ulujami want students to be able to interact directly with their environment and show that the Pemalang community that has its own identity that can be continued by its generation. This was stated by one of the history teachers of SMA Negeri 1 Ulujami, Tina Sunarni, that students should be proud to be part of the Pemalang District community because the Pemalang District in the past also had an important role for the struggle of the Indonesian nation [13]. Pemalang community struggle is no less great than the struggle of figures in the territory of Indonesia which are often featured in history textbooks. The accompanying teacher also explained to the students that the Pemalang community in the past had highly upheld social and cultural values, even though the current 
population of foreigners (Dutch) had arrived and settled in the Pemalang District. Thus, although local sites are considered to be lagging behind in the presence of sophisticated information and communication technology, the sophistication in conveying the social identity of the local community to the younger generation cannot be underestimated.

\section{A. Social Identity Formed by Adolescent of SMA} Negeri 1 Ulujami in Visiting Local Sites

In viewing the formation of social identity in adolescents at SMA Negeri 1 Ulujami during the activities of visiting local sites, the researchers used conceptualization and operationalization of social identity based on four main dimensions of Jackson and Smith. The analysis of researchers in each process of forming social identity, as follows:

\section{1) Perceptions of the Intergroup Context}

Means to build the perception of adolescents from SMA Negeri 1 Ulujami in inter-group contexts can be seen in the delivery of teachers about Pemalang's position which is no less important than other regions, such as Tegal and Pekalongan. The Pemalang Regency is a region of Central Java between Tegal and Pekalongan. The existence of the Tegal and Pekalongan areas is somewhat greater than that of the Pemalang region. However, the history teachers at SMA Negeri 1 Ulujami developed a positive perception of the Pemalang region with the existence of many local sites found in the Pemalang District. For example at the New Comal Sugar Factory Site, the teacher shows the economic sector in terms of sugar production developing rapidly in the Pemalang region through the local site. The existence of a sugar factory signifies the fertility of sugar cane farming which is managed by the local community in hard work, where Pemalang is one of the biggest sugar producers in the Tegal Residency. Another interesting thing that was conveyed by the teacher in conveying the social identity of the Pemalang community, namely when he was at the Dutch House Site. The teacher said that in the midst of the arrival of the Dutch and other ethnicities to the Pemalang Regency, the local people of Pemalang continued to uphold Pemalang's social identity, such as Javanese with a diverse Pemalang dialect, mutual cooperation culture, friendly society, and polite behavior. With the determination of the Pemalang community in the past to maintain their social identity, it can still be felt until the next generation. Through the historical approach as explained by the teachers of SMA Negeri 1 Ulujami during the activity, the adolescents of SMA Negeri 1 Ulujami began to give positive perceptions related to the region (in-group). Thus, adolescents of SMA Negeri 1 Ulujami did not hesitate to recognize themselves as part of Pemalang society with all inherent characteristics, ranging from language, culture, and social, as well as providing a perspective that the social identity that characterizes Pemalang must continue to be preserved by generations successor.

\section{2) Attraction to the In-Group}

The positive perception conveyed by the teachers to adolescents at SMA Negeri 1 Ulujami about all special characteristics of the social identity of the Pemalang community presents a feeling of pride in the area of residence (in-group). This is as expressed by some students who take part in visiting local sites. Wulandari (Students of Class XI IPS 3) expressed admiration that the location that was often passed by there was a local site, where it showed the area where he lived was very historic for Pemalang District [14]. Safitri (Students of Class XI IPS 2) also gives a similar appeal to the area of residence [15]. Meanwhile, 14 other students including resource persons also gave a positive response to the existence of the area of their residence, namely the Pemalang District, which has many distinctive features and also influenced the Indonesian civilization. In addition, the appeal of adolescents at Ulujami 1 High School helped instill positive social identity with the awareness that every Pemalang community must protect the surrounding environment, as well as maintain politeness, ways of speaking, and good behavior such as Pemalang's social identity that has existed for a long time [16].

\section{3) Interdependency Beliefs (Common Fate)}

Individuals who already have confidence in their social groups will appear emotional closeness. Emotional closeness is formed with individuals getting to know more about the group (in-group). This was experienced by adolescents at SMA Negeri 1 Ulujami, who felt close to all aspects of the area of their residence through local sites and the direction of history teachers of SMA Negeri 1 Ulujami when the activity took place. Feeling proud of his social group is related to the historical appreciation of the area where he lives (Pemalang), so it can make the adolescents of SMA Negeri 1 Ulujami will be proud and confident in Pemalang's social identity.

\section{4) Depersonalization}

Depersonalization is the final dimension of social identity formation according to Jackson and Smith. When individuals already feel part of a group, then the individual tends to use the values in the group to be applied to him. At this stage, visiting local sites influences students' selfidentity, that they are all part of the Pemalang community who have the same social identity. This social identity embodies adolescents of SMA Negeri 1 Ulujami to jointly uphold positive values developed in society.

\section{CONCLUSION}

Based on the results of this study, the researchers concluded that the formation of social identity sourced from the community is very important for adolescents who are seeking identity. It is performed to make adolescents get closer emotionally and realize that the region has a unique social identity. The feeling of having a social identity in the region can lead to an attachment between communities to foster harmony, realizing that between members have the same identity that distinguishes it from other regions. Therefore, the formation of social identity in adolescents needs to be done with a community environmental approach so that the social identity that is intended to be built is more effectively conveyed, one of them through local sites. Local sites provide a lot of images about cultural treasures, objects of knowledge, sources of data and historical evidence, mirrors the culture and history of the nation, media education, development, and build of national cultural 
values, and media to foster the personality of the local community. Through proper packaging and delivery, adolescents will get a valuable picture of social identity through local sites. In the end, positive local social identity can be accepted by adolescents as the next generation of the local area.

\section{ACKNOWLEDGMENT}

The authors would like to thank the teachers and students at SMA Negeri 1 Ulujami who have helped in gathering resources and information. We also thank our family, State University Yogyakarta, and many people that cannot be mentioned one by one in here.

\section{REFERENCES}

[1] T. J. Lan, "Heterogeneity, politics of ethnicity, and multiculturalism: what is a viable framework for Indonesia?", in Journal of Wacana 13 (2), Faculty of Humanities, University of Indonesia, 2011, p. 279-292.

[2] C. V. Laar, B. Derks, N. Ellemers, and D. Bleeker, "Valuing social identity: consequences for motivation and performance in low-status groups", in Jornal of Social Issues 66 (3), 2010, p. 602-617.

[3] J. W. Santrock, Psikologi Pendidikan, Jakarta: Salemba Humanika, 2014, p. 81-85.

[4] L. Althusser, On the Reproduction of Capitalism: Ideology Ideological State Apparatuses, 2014, p. 218.
[5] Septiarti, et al, Sosiologi dan Antropologi Pendidikan, Yogyakarta: UNY Press, 2017, p. 2.

[6] Sugiyono, Metode Penelitian \& Pengembangan: Research and Development, Bandung: Alfabeta, 2017, 125-126.

[7] H. Tajfel, Social Psychology of Intergroup Relations, England, 1982, p. 24.

[8] J. E. Stets and J. P. Burke, "Identity theory and social identity theory", in Social Psichology Quarterly, 2000, accessed on http://www.jstror.org/pss/2786796, dated on April 12 $2^{\text {th }}, 2020$.

[9] H. Tajfel, Social Psychology of Intergroup Relations, England, 1982, p. 24.

[10] J. W. Jackson and E. R. Smith, "Conceptualizing social identity: a new framework and evidence for the impact of different dimensions", in Personality and Social Psychology Bulletin, 1999, p. 120-135.

[11] Presiden Republik Indonesia, Undang-Undang Republik Indonesia Nomor 5 Tahun 1992 Tentang Cagar Budays, Jakarta, 1992.

[12] E. Kusmanta (History Teacher at SMA Negeri 1 Ulujami), interviewed on August $5^{\text {th }}, 2019$.

[13] T. Sunarni (History Teacher at SMA Negeri 1 Ulujami), interviewed on August $5^{\text {th }}, 2019$.

[14] V. A. Wulandari (Student of XI IPS 3 at SMA Negeri 1 Ulujami), interviewed on January $28^{\text {th }}, 2020$.

[15] L. B. Safitri (Student of XI IPS 2 at SMA Negeri 1 Ulujami), interviewed on January $29^{\text {th }}, 2020$.

[16] L. A. Ningrum (Student of XI IPS 2 at SMA Negeri 1 Ulujami), interviewed on January $29^{\text {th }}, 2020$ 